\title{
Regulation of AMH by oocyte-specific growth factors in human primary cumulus cells
}

\author{
Scott Convissar ${ }^{1}$, Marah Armouti ${ }^{1}$, Michelle A Fierro², Nicola J Winston², Humberto Scoccia ${ }^{2}$, \\ A Musa Zamah² and Carlos Stocco ${ }^{1}$ \\ ${ }^{1}$ Department of Physiology and Biophysics, The University of Illinois at Chicago College of Medicine, Chicago, \\ Illinois, USA and ' Division of Reproductive Endocrinology and Infertility, Department of Obstetrics and Gynecology, \\ The University of Illinois at Chicago College of Medicine, Chicago, Illinois, USA \\ Correspondence should be addressed to C Stocco; Email: costocco@uic.edu
}

\begin{abstract}
The regulation of AMH production by follicular cells is poorly understood. The purpose of this study was to determine the role of the oocyte-secreted factors, growth differentiation factor 9 (GDF9) and bone morphogenetic protein 15 (BMP15), on AMH production in primary human cumulus cells. Cumulus cells from IVF patients were cultured with a combination of GDF9, BMP15, recombinant FSH and specific signaling inhibitors. Stimulation with GDF9 or BMP15 separately had no significant effect on AMH mRNA levels. In contrast, simultaneous stimulation with GDF9 and BMP15 $(G+B)$ resulted in a significant increase in $A M H$ mRNA expression. Increasing concentration of $G+B(0.6,2.5,5$ and $10 \mathrm{ng} / \mathrm{mL})$ stimulated $A M H$ in a dose-dependent manner, showing a maximal effect at $5 \mathrm{ng} / \mathrm{mL}$. Western blot analyses revealed an average 16 -fold increase in AMH protein levels in cells treated with $G+B$ when compared to controls. FSH co-treatment decreased the stimulation of $A M H$ expression by $G+B$. The stimulatory effect of $G+B$ on the expression of AMH was significantly decreased by inhibitors of the SMAD2/3 signaling pathway. These findings show for the first time that AMH production is regulated by oocyte-secreted factors in primary human cumulus cells. Moreover, our novel findings establish that the combination of GDF9 + BMP15 potently stimulates AMH expression.

Reproduction (2017) 154 745-753
\end{abstract}

\section{Introduction}

Ovulation results from a lengthy process known as folliculogenesis, which comprises primordial follicle recruitment, followed by granulosa cell (GC) proliferation and differentiation leading to antral/preovulatory follicle formation. Throughout folliculogenesis, bidirectional communication between the oocyte and the GCs is essential to create the microenvironment necessary for normal follicle growth. Despite its importance, most, if not all, reported work on oocyte-GC interactions is based on studies in rodents. Therefore, further research is essential to understand the nature of the dialogue between the oocyte and the GCs in humans.

Growth differentiation factor 9 (GDF9) and bone morphogenetic protein 15 (BMP15) are two of the major oocyte-secreted factors involved in the regulation of GC function. GDF9 and BMP15 cooperate to regulate GC proliferation and gonadotropin-induced differentiation (McNatty et al. 2005a,b, Mottershead et al. 2012). In mice and sheep, GDF9 is essential not only for the stimulation of early follicular growth but also for cumulus expansion, ovulation and fertility (Elvin et al. 1999, Hayashi et al. 1999). In rodents, BMP15 promotes GC proliferation and inhibits FSH-induced progesterone synthesis (Otsuka et al. 2000). However, BMP15-knockout female mice exhibit normal folliculogenesis with slightly dysfunctional ovulation resulting in subfertility (Yan et al. 2001, Yoshino et al. 2006). In contrast, in humans and sheep, homozygous mutations of the BMP15 gene cause infertility (Galloway et al. 2000, Di Pasquale et al. 2004). This evidence led to the notion that BMP15 has species-specific functions, being more important in mono-ovulatory mammals but largely superfluous in mice (Su et al. 2004, Al-Musawi et al. 2013, Monestier et al. 2014). GDF9 and BMP15 are present in the oocyte on primordial human follicles onward suggesting they are also involved in the control of human folliculogenesis (Sun et al. 2010). Indeed, GDF9 and BMP15 have been shown to play a role in human fertility as demonstrated by the association between mutations in these genes and premature ovarian failure (Di Pasquale et al. 2006, Dixit et al. 2006, Kovanci et al. 2007, Zhao et al. 2007). Moreover, the signaling between the oocyte and the GCs is impaired in patients with polycystic ovary syndrome a condition whose main characteristics are folliculogenesis disruption and subfertility 
(Teixeira Filho et al. 2002, Dumesic \& Richards 2013). However, the specific reciprocal interactions between the oocyte and GCs that are mediated by GDF9 and BMP15 in humans remain unexplored.

$\mathrm{AMH}$ was initially identified as a testicular factor involved in the regression of Müllerian ducts during male sex differentiation (Blanchard \& Josso 1974). However, $\mathrm{AMH}$ is also expressed in the GCs of primary follicles, the first stage of follicular development (Dumont et al. 2015). Thereafter, AMH expression increases in growing follicles until they reach the antral stage, from which point $\mathrm{AMH}$ expression decreases and is undetectable in large preovulatory follicles in rodents and humans (Dewailly et al. 2014). In humans, in particular, several studies demonstrated that $\mathrm{AMH}$ remains highly expressed until follicles reach a diameter of approximately $8 \mathrm{~mm}$ (Weenen et al. 2004, Andersen et al. 2010, Jeppesen et al. 2013). Accordingly, in women, AMH levels in follicular fluid from small antral follicles are 2-3 orders of magnitude higher than that in the fluid from preovulatory follicles (Andersen \& Byskov 2006). Serum AMH levels also decrease with age and eventually become undetectable at menopause (Dolleman et al. 2014). Moreover, AMH declines prematurely due to events associated with ovarian aging (de Vet et al. 2002), dysfunction such as premature ovarian failure (Meduri et al. 2007) or after gonadotoxic chemotherapy (Dunlop \& Anderson 2015). Based on this particular pattern of expression, it has been proposed that $\mathrm{AMH}$ levels can be used to determine the size of the ovarian follicular reserve (Visser et al. 2012, Pankhurst 2017). Despite the importance of $\mathrm{AMH}$ as a clinical marker of ovarian reserve, the regulatory network controlling $\mathrm{AMH}$ expression in the ovary is poorly understood especially in humans.

In cultured mouse GCs, $\mathrm{AMH}$ increases after the addition of oocytes to the culture media, although the specific factors involved are unknown (Salmon et al. 2004). This suggests that oocyte-secreted factors may participate in the regulation of $\mathrm{AMH}$. Here, we studied the regulation of $\mathrm{AMH}$ expression in primary human cumulus cells, which is the sub-population of GCs surrounding the oocyte. Previous reports from our laboratory demonstrated that cumulus cells obtained from IVF patients respond to gonadotropins and growth factors and can be used as a proxy of undifferentiated preantral GCs (Baumgarten et al. 2014, 2015, Stocco et al. 2017). Thus, the aim of this investigation was to determine the role of GDF9, BMP15 and FSH on the regulation of $\mathrm{AMH}$ in human cumulus cells. In addition, recent findings demonstrated that GDF9 and BMP15 form heterodimers (GDF9:BMP15), which are significantly more active than their respective homodimers (Peng et al. 2013, Mottershead et al. 2015). Therefore, the effect of the combined treatment with GDF9 and BMP15 on the expression of AMH was also examined.

\section{Material and methods}

\section{Patients and human cumulus cell culture}

Cumulus cells were collected from the follicular aspirates of women undergoing in vitro fertilization treatment at the University of Illinois at Chicago Fertility Center, under Institutional Review Board approval. All participants gave written informed consent. Only patients with male, uterine or tubal factor infertility were included. After controlled ovarian hyperstimulation with gonadotropins, patients underwent transvaginal oocyte retrieval, follicular aspirates were collected and CCs were mechanically separated from the oocytes. Isolated CCs were transported immediately to the laboratory where they were dispersed by hyaluronidase digestion $(8 \mathrm{IU} / \mu \mathrm{L})$ and then centrifuged at $500 \mathrm{~g}$ for $5 \mathrm{~min}$. Cells were incubated at room temperature in red blood cell lysis buffer for $2 \mathrm{~min}$ to eliminate contaminating erythrocytes, centrifuged again at $500 \mathrm{~g}$ for $5 \mathrm{~min}$ and suspended in $0.5 \mathrm{~mL}$ of serum-free DMEM/ F12-0.25\% BSA media containing antibiotics. To investigate mRNA expression or promoter activity, cells were plated at a density of 30,000 cells/well in 24-well plates coated with Matrigel (DB Biosciences, San Jose, CA, USA). To investigate protein expression, cells were plated at a density of 200,000 cells/well in 6-well Matrigel-coated plates. Cumulus cells were treated with human recombinant GDF9 (R\&D Systems), BMP15 (R\&D Systems) and/or FSH (Serono) with or without specific inhibitors of intracellular signaling; H89, GF109203X (EMD Biosciences-Calbiochem), MK2206, LDN-193189 (Selleck Chemicals, Houston, TX, USA), U0126 (Millipore) or SB431542 (Tocris, Minneapolis, MN, USA). Each data point reflects a result obtained from an individual patient. Cells from each patient were cultured separately. GDF9 and BMP15 from R\&D systems are produced in HEK293 cells; therefore, these ligands are expected to be glycosylated and mimic the effect of the natural ligands as previously shown by Peng and coworkers (Peng et al. 2013).

\section{RNA extraction and quantitative real-time PCR (qPCR)}

Total RNA was isolated from CCs using the TRIzol reagent (Invitrogen) as stated in the manufacturer's protocol. The isolated RNA was reverse transcribed using anchored oligo-dT primers (IDT, Coralville, IA) and Moloney Murine Leukemia Virus reverse transcriptase (Invitrogen) at $42^{\circ} \mathrm{C}$ for $1 \mathrm{~h}$. The resulting cDNA was diluted with water to a final volume of $100 \mu \mathrm{L}$ and $5 \mu \mathrm{L}$ of diluted cDNA was used for each qPCR reaction. For each sample, Amh expression was adjusted to the expression of ribosomal protein L19 mRNA (Rp/19) as an internal control. Primer sequences are Amh; gctgccttgccctctctac and gaacctcagcgagggtgtt, Rp/19; tgttttccggcatcgagccc and gctgtggcaagaagaaggtctgg.

\section{Promoter reporter assays}

$\mathrm{AMH}$ reporters were generated by cloning the $-521,-1440$ or -2222 upstream region of the human $\mathrm{AMH}$ promoter, followed by the firefly luciferase cDNA, into pTRIP plasmid (Stove et al. 2006). Lentiviruses containing this construct were generated as previously described (Zhou et al. 2013). All constructs contain in addition an expression cassette for green 
fluorescence protein (GFP), which allows the determination of infection efficiency. In all experiments, the infection efficiency was higher than $90 \%$ as determined by the number of cells expressing GFP. Empty pTRIP plasmids were used as controls (Luc). To analyze promoter activity, cells were infected with lentiviral constructs for $48 \mathrm{~h}$ followed by 6 - $\mathrm{h}$ treatments with $\mathrm{G}+\mathrm{B}$. Luciferase activity was determined in $50 \mu \mathrm{L}$ of cell lysate as previously described (Zhou et al. 2013).

\section{Western blot}

Cultured cumulus cells were harvested in ice-cold RIPA lysis buffer supplemented with protease inhibitor cocktail (Sigma). Protein concentration and Western blotting of cell lysate were performed as previously described (Bennett et al. 2013). Antibodies against AMH (1:500; R\&D Systems) and ACTB (1:1000; Proteintech) were used to detect total protein expression by Western blot as previously described (Baumgarten et al. 2014).

\section{Statistical analysis}

Graphed data represent the mean value \pm S.E.M. For $q P C R$ and Western blot, statistical analysis was performed using $t$-test or one-way analysis of variance (ANOVA). Differences between groups were statistically significant as indicated in the figure legend.

\section{Results}

\section{Stimulatory effect of the GDF9 and BMP15 combination on AMH $m R N A$ expression}

To determine the effect of oocyte-derived factors on $\mathrm{AMH}$ regulation in human $\mathrm{GCs}$, we used a recently developed primary culture of human cumulus cells from IVF patients (Stocco et al. 2017). Human cumulus cells were treated with recombinant human GDF9 or recombinant human $\mathrm{BMP} 15$ at 2.5 and $10 \mathrm{ng} / \mathrm{mL}$. In addition, cells were treated with a combination of GDF9 plus BMP15 $(\mathrm{G}+\mathrm{B})$ at $0.1,0.6,5$ or $10 \mathrm{ng} / \mathrm{mL}$ of each factor. Treatment with GDF9 alone had no effect on the expression of $A M H$ at any of the concentrations used. Treatment with BMP15 alone tended to stimulate $A M H$ expression, particularly at the $2.5 \mathrm{ng} / \mathrm{mL}$ concentration, although this increase did not reach statistical significance when compared using one-way ANOVA. In contrast, treatment with $\mathrm{G}+\mathrm{B}$ stimulated $A M H \mathrm{mRNA}$ accumulation in a dose-dependent manner (Fig. 1). Cumulus cells exposed to $0.6 \mathrm{ng} / \mathrm{mL}$ of $\mathrm{G}+\mathrm{B}$ showed some increase in $A M H$ expression, whereas a significant increase in the expression of $A M H$ was detected with 5 or $10 \mathrm{ng} / \mathrm{mL}$ of $\mathrm{G}+\mathrm{B}$ (Fig. 1). It is noteworthy that although the GDF9 and BMP15 co-treatment at 5 and $10 \mathrm{ng} / \mathrm{mL}$ consistently stimulated $A M H$ in all patients examined, we observed high variability in the response of cumulus cells to $10 \mathrm{ng} / \mathrm{mL}$. For this reason, we used $5 \mathrm{ng} / \mathrm{mL}$ of each GDF9 and BMP15 in all further experiments.

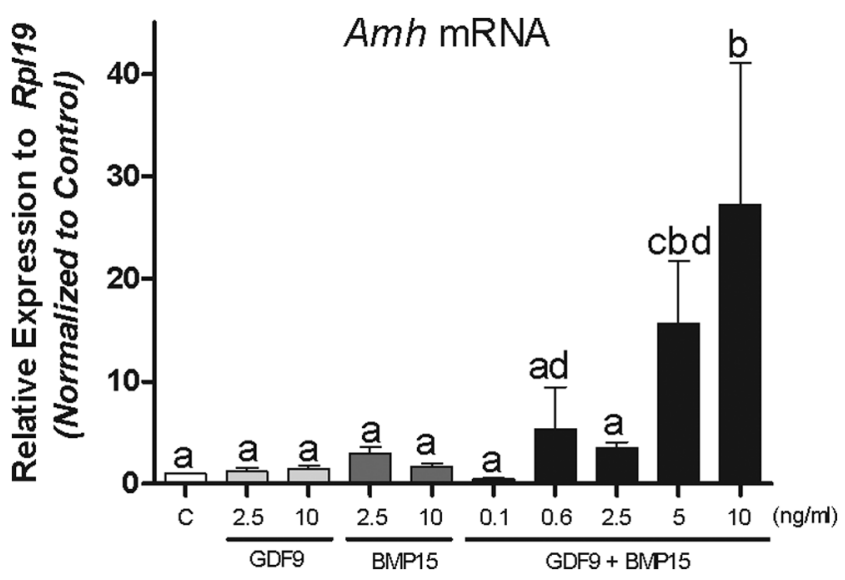

Figure 1 The combination of GDF9 and BMP15 stimulate AMH mRNA expression in human cumulus cells. Cumulus cells were treated for $48 \mathrm{~h}$ with vehicle (C), GDF9 $(2.5,10 \mathrm{ng} / \mathrm{mL})$, BMP15 $(2.5,10 \mathrm{ng} / \mathrm{mL})$ or the combination of GDF9 and BMP15 $(0.1,0.6,2.5,5$ or $10 \mathrm{ng} / \mathrm{mL}$ of each). AMH mRNA levels were determined by qPCR and expressed as relative to $R P L 19$. Columns represent the mean \pm S.E.M. Columns with different letters differ significantly a-b: $P<0.05$, a-c: $P<0.001$ vs controls, one-way ANOVA, Bonferroni test, $n=15$.

\section{The combination of GDF9 and BMP15 strongly stimulates $\mathrm{AMH}$ protein levels}

Next, we investigated whether the stimulation of $\mathrm{AMH}$ mRNA levels by GDF9 and BMP15 translated into an increase in $\mathrm{AMH}$ protein production. Cumulus cells obtained from three different patients were cultured in the presence or absence $\mathrm{G}+\mathrm{B}(5 \mathrm{ng} / \mathrm{mL}$ each). For each patient, $\mathrm{AMH}$ protein expression was readily detectable in cells treated with $\mathrm{G}+\mathrm{B}$ (Fig. 2A). In contrast, $\mathrm{AMH}$

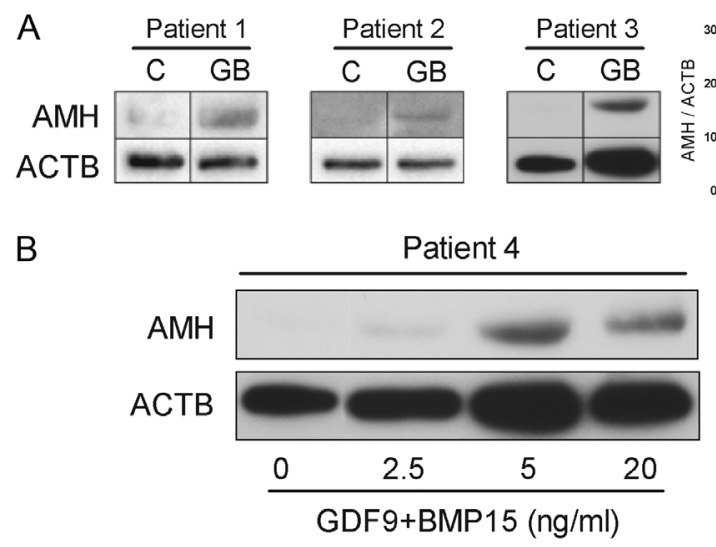

Figure $2 \mathrm{AMH}$ protein levels in human cumulus cells treated with GDF9 and BMP15. (A) Cumulus cells from three different patients (patients 1, 2 and 3) were treated with $5 \mathrm{ng} / \mathrm{mL}$ of both GDF9 and BMP15 (GB) for $48 \mathrm{~h}$. AMH $\beta$-actin (ACTB) protein levels were determined by Western blotting. On the left, the average ( \pm S.E.M.) of the relative optical density units of $\mathrm{AMH}$ to $\mathrm{ACTB}$ is shown (**P $P<0.001$, $t$-test, $n=3$ ). (B) Cumulus cells from patient 4 were treated with 2.5, 5, or $20 \mathrm{ng} / \mathrm{mL}$ of both GDF9 and BMP15. AMH protein levels were determined as in A. Expression of ACTB is shown as a loading control. 
was barely detectable in control conditions. An increase in AMH protein levels was observed in cells treated with GDF9 and BMP15 when compared to controls. The ratio of the densitometry analysis of $\mathrm{AMH}$ and $\beta$-actin signal indicated that the relative expression of $\mathrm{AMH}$ protein in $\mathrm{G}+\mathrm{B}$ treated cells is higher than that in vehicle-treated cells (Fig. 2A). Additionally, a dose-dependent experiment was conducted with cells from a fourth patient. For this experiment, $\mathrm{AMH}$ was undetectable in untreated cells. A small increase in $\mathrm{AMH}$ was observed with $\mathrm{G}+\mathrm{B}$ at $2.5 \mathrm{ng} / \mathrm{mL}$ each. Protein expression increased further in cells treated with $5 \mathrm{ng} / \mathrm{mL}$ of $\mathrm{G}+\mathrm{B}$ (Fig. 2B). Interestingly, although a concentration of $20 \mathrm{ng} / \mathrm{mL}$ of $\mathrm{G}+\mathrm{B}$ also stimulated the $\mathrm{AMH}$ protein expression, the stimulation obtained with this concentration was lower than the one obtained with $5 \mathrm{ng} / \mathrm{mL}$. Thus, in good agreement with our findings at the mRNA level, a concentration of $5 \mathrm{ng} / \mathrm{mL}$ of $\mathrm{G}+\mathrm{B}$ most effectively stimulates $\mathrm{AMH}$ protein expression.

\section{GDF9 and BMP15 have no major effect on the stimulation of AMH promoter activity}

Different lengths of the promoter region of the $A M H$ gene were cloned into a reporter vector. These reporters were transfected into cumulus cells using a lentivirus system, which provides the highest infection efficiency usually more than $90 \%$ as determined by the expression of GFP (see Material and Methods section). Forty-eight hours after transfection, cells were treated with vehicle or the combination of GDF9 and BMP15 at $5 \mathrm{ng} / \mathrm{mL}$ of each. Luciferase activity was quantified 6 and $24 \mathrm{~h}$ after the initiation of the treatments. Treatment with GDF9 and BMP15 had no effect on the activity of reporter constructs carrying 521, 1440 or 2222 bps of the AMH promoter most adjacent to the transcription start site (Supplementary Fig. 1, see section on supplementary data given at the end of this article).

\section{FSH diminishes the stimulatory effect of GDF9 and BMP15 on AMH}

It has been recognized that the expression of $\mathrm{AMH}$ decreases as GCs differentiate to the preovulatory stage, a process largely controlled by $\mathrm{FSH}$. Therefore, next, we examined whether co-treatment with $\mathrm{FSH}$ had any effect on the stimulation of $A M H$ mRNA by $\mathrm{G}+\mathrm{B}$. For this purpose, cumulus cells were treated with GDF9 and BMP15 in the presence or absence of FSH for $48 \mathrm{~h}$. An additional group of cells was treated with FSH alone. As shown in Fig. 3, treatment with FSH alone had no effect on $A M H$ mRNA levels. As expected, all groups treated with $\mathrm{G}+\mathrm{B}$ showed increased $A M H$ expression. However, this increase was blunted in the presence of $\mathrm{FSH}$ suggesting that FSH inhibits the stimulation of $\mathrm{AMH}$ by GDF9 and BMP15.

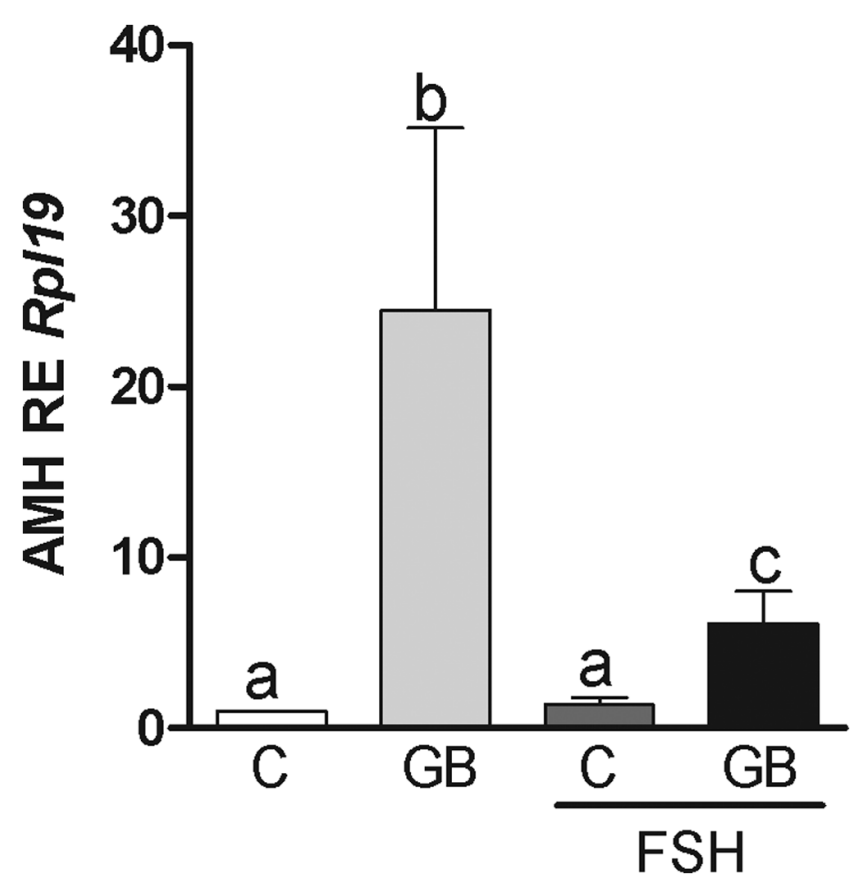

Figure $3 \mathrm{FSH}$ inhibits the stimulation of GDF9 and BMP15 on $A M H$ mRNA expression. Cumulus cells were treated for $48 \mathrm{~h}$ with GDF9 and BMP15 $(\mathrm{G}+\mathrm{B} ; 5 \mathrm{ng} / \mathrm{mL}$ of each) in the presence or absence of FSH $(50 \mathrm{ng} / \mathrm{mL})$. AMH mRNA levels were determined by qPCR and expressed relative to RPL19. Columns with different letters differ significantly a-b: $P<0.001$, a-c: $P<0.05$, b-c: $P<0.01$, one-way ANOVA, Bonferroni test, $n=11$.

\section{Role of SMAD on AMH regulation in human granulosa cells}

The signaling used by BMP15 and GDF9 in human granulosa cells has not been examined. It has been

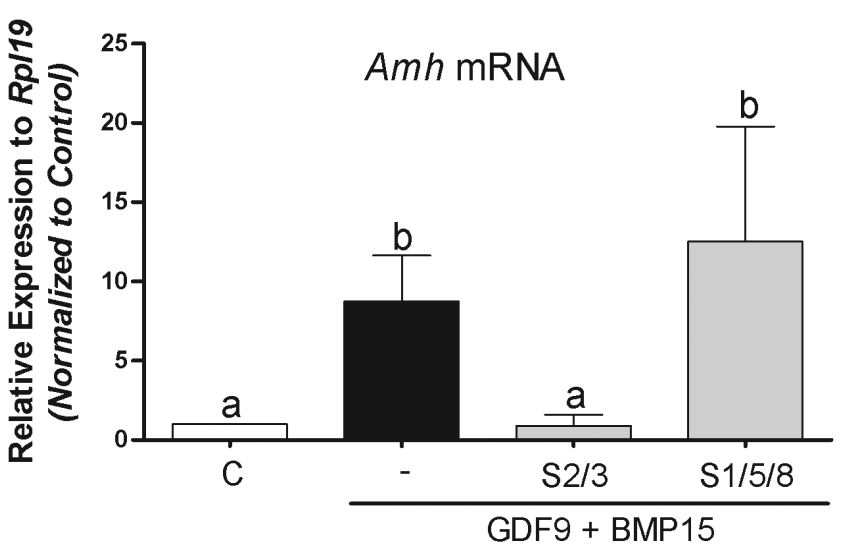

Figure 4 Effect of cell signaling inhibition on GDF9- and BMP15induced $A M H$ mRNA levels. Cumulus cells were treated for $1 \mathrm{~h}$ with the following specific SB431542 (SMAD2/3; $10 \mu \mathrm{M}$ ), or LDN-193189 (SMAD1/5/8; $100 \mathrm{nM}$ ) followed by a 48-h co-treatment with GDF9 and BMP15 ( $5 \mathrm{ng} / \mathrm{mL}$ of each). AMH mRNA levels were determined $48 \mathrm{~h}$ after by qPCR and expressed relative to RPL19. Columns with different letters differ significantly a-b: $P<0.001$, one-way ANOVA, Bonferroni test, $n=9$. 
shown that BMP15 activates the SMAD1/5/8 signaling pathway, whereas GDF9 signals through SMAD2/3 (Moore et al. 2003, Mazerbourg et al. 2004). To elucidate whether these pathways mediate $\mathrm{G}+\mathrm{B}$ actions on $\mathrm{AMH}$, cumulus cells were treated with inhibitors of SMAD2/3 (SB431542) or SMAD1/5/8 (LDN-193189) for one hour before the addition of GDF9 and BMP15 to the media. Forty-eight hours later, cells were harvested for AMH mRNA determination. The results indicated that inhibition of SMAD1/5/8 had no major effects on the induction of $A M H$ levels by $G+B$ (Fig. 4). However, a strong inhibition was observed with SB431542 (Fig. 4), which selectively inhibits SMAD2/3 (Inman et al. 2002).

\section{Discussion}

In mice, $\mathrm{AMH}$ knockdown increases the entry rate of primordial follicles into the growing follicle pool (Durlinger et al. 1999), indicating that AMH is involved in regulating primordial follicle recruitment. $\mathrm{AMH}$ also acts in antral follicles where it blocks FSH induction of aromatase expression and estradiol production, two markers of preovulatory GC differentiation (Durlinger et al. 2001). In humans, a similar relationship appears to exist, as follicular $\mathrm{AMH}$ and estradiol levels are inversely correlated in small antral follicles (Andersen \& Byskov 2006). These studies indicate that appropriate regulation of $\mathrm{AMH}$ expression is critical throughout folliculogenesis and highlight the urgent need to investigate the molecular mechanisms controlling this important reproductive hormone, especially in humans. Our results have established that AMH expression increases more than 10-fold in primary human cumulus cells co-treated with the oocytesecreted factors GDF9 and BMP15. This observation suggests that by modulating $\mathrm{AMH}$, the oocyte may play a role in the control of follicle recruitment and dominant follicle selection in humans.

Co-treatment of cumulus cells with low concentrations of GDF9 and BMP15 induced AMH expression. However, treatment with either GDF9 alone had no effect, whereas treatment with BMP15 stimulates AMH to levels that are significantly lower than those induced by GDF9+BMP15. These results suggest that GDF9 and BMP15 interact to control AMH expression in human GCs. The strong synergism between GDF9 and BMP15 on AMH expression is likely to be attributed to the formation of GDF9:BMP15 heterodimers (Yan et al. 2001, Liao et al. 2003, Peng et al. 2013), named 'cumulin' (Mottershead et al. 2015). This last report showed that cumulin forms after the simple co-addition of GDF9 and BMP15 to the culture medium and that the effect of the cotreatment with GDF9 and BMP15 cannot be mimicked by the co-addition of GDF9 and BMP15 stable homodimers (Mottershead et al. 2015). Of note, previous reports have used highly sensitive mouse GCs isolated from preantral follicles to study the effects of purified GDF9:BMP15 heterodimers (Peng et al. 2013, Mottershead et al. 2015). The fact that the combination of GDF9 and BMP15 behave similarly in primary human cumulus cells is remarkable and provides further support for the use of cumulus cells to study follicular cell differentiation and the role of oocyte-secreted factors in the regulation of GC function.

In this regard, as discussed in the introduction, we used in this report a novel experimental approach to study $\mathrm{AMH}$ regulation, which consists of cumulus cells from IVF patients. We have recently fully characterized this model and extensively discussed the fact that human cumulus cells from IVF do not luteinize and respond to gonadotropins, and IGFs as cells from preantral follicles do (Stocco et al. 2017). This model was also used and validated in two recent publications (Baumgarten et al. 2014, 2015). It must also be highlighted that cumulus cells are the natural and physiological targets of oocytesecreted factors (GDF9 and BMP15). Therefore, this model is not only novel but also provides a more physiological approach to study AMH regulation. However, since the regulation of $\mathrm{AMH}$ expression may differ significantly between undifferentiated granulosa cells, mural granulosa cells and cumulus cells, the effect of GDF9 and BMP15 on AMH in other types of follicular cells requires further studies.

We based our dose-response experiments on published data from two independent groups (Peng et al. 2013, Mottershead et al. 2015). So far, there are few reports in the literature on the levels of GDF9 and BMP15 in normal follicular fluid; whereas there are no publications reporting levels of the heterodimer. In women with primary or secondary infertility for diminished ovarian reserve, BMP15 and GDF9 levels in the follicular fluid at oocyte retrieval were reported to be $0.81( \pm 0.25) \mathrm{ng} / \mathrm{mL}$ and $6.82( \pm 3.77) \mathrm{ng} / \mathrm{mL}$ respectively (Zhang et al. 2014). Also in the follicular fluid at oocyte retrieval of women underdoing in vitro fertilization, BMP15 levels were reported at $278( \pm 12) \mathrm{ng} / \mathrm{mL}$ (Ilhan et al. 2017), whereas another independent study reported GDF9 levels of $6.8( \pm 0.9) \mathrm{ng} / \mathrm{mL}$ in the follicular fluid of women aged younger than 35 years (Han et al. 2011). It is difficult to extrapolate the in vitro concentrations of GDF9 and BMP15 used in the literature and in this report to GDF9 and BMP15 levels in the follicular fluid, especially considering that these factors are locally produced, and therefore, they may reach high local concentrations. Despite this limitation, the concentrations we have used are in the low range of the follicular fluid concentrations reported for these factors. GDF9 and BMP15 are detectable in human follicular fluid using Western blot and mature GDF9 levels in the follicular fluid are significantly correlated with oocyte nuclear maturation and embryo quality (Gode et al. 2011). The development of sensitive assays for GDF9 and BMP15 that can distinguish the most 
biologically potent GDF9:BMP15 heterodimer will be a great tool to better understand the role of these factors in human ovarian function.

It has been previously demonstrated that GDF9 slightly enhances the stimulatory effect of BMP15 alone on AMH expression in ovine GCs obtained from preantral follicles (Pierre et al. 2016). In contrast, we observed a strong synergism between GDF9 and BMP15 on the expression of $\mathrm{AMH}$ in humans, whereas either factor has negligible effects on AMH. Species differences may account for this discrepancy although the concentration of GDF9 and BMP15 used in each study should also be considered. For instance, we observed that concentrations higher than $10 \mathrm{ng} / \mathrm{mL}$ are less efficient at inducing AMH expression at both the mRNA and protein levels. In the above-mentioned report, ovine GCs were treated with $50 \mathrm{ng} / \mathrm{mL}$ of each factor. This suggests that at higher concentrations the formation of GDF9:BMP15 heterodimers may be impaired. However, it is also possible that the receptors used by the heterodimers are not expressed in ovine GCs or that the heterodimers are more active in human than in ovine GCs. An example of this possibility is that in ovine GCs, Pierre and coworkers could show an increase in AMH promoter activity after treatment with GDF9 and BMP15 (Pierre et al. 2016). In contrast, we were not able to do so, suggesting speciesspecific differences. Further studies are needed to determine the species-specific effects of GDF9:BMP15 heterodimers. Finally, in ovine GCs, Pierre and coworkers only reported mRNA levels for $\mathrm{AMH}$, which is not enough to conclude that the $\mathrm{AMH}$ protein is also stimulated by GDF9 and BMP15 (Pierre et al. 2016). In contrast, we have correlated mRNA levels with protein expression using dose-response experiments. Thus, our report demonstrates for the first time a stimulatory effect of GDF9 and BMP15 on AMH expression in primary human cumulus cells.

Pierre and coworkers also used mural luteinized granulosa cells from IVF patients (Pierre et al. 2016). However, in contrast to our findings, this report showed that there are no significant differences between BMP15 and BMP15 + GDF9 treatments on AMH mRNA levels in human luteinized granulosa cells (Fig. 1D on Pierre et al. 2016). These findings show that mural cells are not the ideal model to study $\mathrm{AMH}$ regulation. This idea is supported by the AMH regulation in GCs. For instance, Campbell and coworkers demonstrated that $\mathrm{AMH}$ remains expressed in cumulus cells while it becomes very reduced in the mural GCs of large follicles (Campbell et al. 2012). Moreover, after the administration of human chorionic gonadotropin (hCG) to IVF patients, mural cells undergo terminal differentiation toward luteinization and therefore shut down $\mathrm{AMH}$ expression (Grondahl et al. 2011, Kedem-Dickman et al. 2012, Merhi et al. 2013). Thus, AMH mRNA is absent in preovulatory follicles and corpora lutea (Baarends et al. 1995). Therefore, our results in cumulus cells are not only novel but also entirely different to those obtained by Pierre and coworkers using luteinized granulosa cells (Pierre et al. 2016).

The stimulatory effect of GDF9 plus BMP15 on the activity of $\mathrm{AMH}$ promoter reporter constructs was minimal when compared to the effect of this combination on AMH mRNA and protein levels. This finding suggests that mechanisms other than the activation of gene expression may be involved in the regulation of $\mathrm{AMH}$ by GDF9 and BMP15 in primary human cumulus cells. Also, it is possible that additional elements beyond the $2.2 \mathrm{~kb}$ promoter region used in this report are involved in $\mathrm{AMH}$ regulation in primary human cumulus cells. Despite this controversy, our findings prove that the SMAD2/3 signaling pathway play a crucial role in the induction of $\mathrm{AMH}$ in these cells. In COV434 cells, an ovarian granulosa tumor cell line, GDF9:BMP15 heterodimers signal through a unique receptorsome formed by BMP receptor type 2 (BMPR2) and a type 1 receptor complex composed by ALK4 and ALK6 (a.k.a. ACVR1B and BMPR1B) (Peng et al. 2013). Although we have not determined, which receptors mediate the effect of GDG9 plus BMP15 in primary human cumulus cells, it is possible that ALK4 and ALK6 may be involved since these receptors are known to activate SMAD2/3. Finally, our finding agrees with previous reports demonstrating that GDF9 and BMP15 cotreatment stimulates thymidine incorporation in rat granulosa cells in an SMAD2/3dependent manner (Reader et al. 2011). Together, the evidence points to a crucial role of SMAD2/3 on the regulation of $\mathrm{AMH}$ by GDF9 and BMP15 in human primary GCs.

FSH blunted the effect of GDF9 and BMP15 in human CCs, a finding that resembles the physiological regulation of $\mathrm{AMH}$ during folliculogenesis (see Introduction section). This observation is consistent with previous in vivo findings in rats showing that $\mathrm{FSH}$ decreases $\mathrm{AMH}$ expression in GCs (Baarends et al. 1995). Evidence obtained in a mouse cell line suggests that estrogen receptor $\beta$ mediates the inhibitory effect of $\mathrm{FSH}$ on AMH (Grynberg et al. 2012). The distal promoter of the $\mathrm{AMH}$ gene contains estrogen receptor-binding sites (Picard et al. 1986), suggesting a direct effect of estrogen on $\mathrm{AMH}$. Despite this evidence, the mechanisms involved in the downregulation of $\mathrm{AMH}$ by $\mathrm{FSH}$ in human cumulus cells are currently unknown. Moreover, since FSH and cAMP increase AMH expression in Sertoli cells (Lukas-Croisier et al. 2003), in human granulosaluteal cells and in the mouse KK1 granulosa cell line (Taieb et al. 2011), it is possible that the pathways by which FSH controls AMH may be not only cell but also species specific. In Sertoli cells, the transcription factors SF1, SOX9, WT1 and GATA4 are involved in AMH upregulation (Giuili et al. 1997, Lukas-Croisier et al. 2003, Lasala et al. 2004, 2011). Excluding SOX9, which is not expressed in the ovary, these factors are present in GCs (Salmon et al. 2005) and have binding sites in 
the $\mathrm{AMH}$ promoter. However, whether they mediate the stimulatory effect of GDF9 and BMP15 or the inhibitory effect of FSH remains to be determined.

In conclusion, these results demonstrate for the first time that the cotreatment with GDF9 and BMP15 stimulates $\mathrm{AMH}$ expression in human primary cumulus cells. The induction of $\mathrm{AMH}$ expression by low concentrations of GDF9 and BMP15 and the fact that the treatment with GDF9 or BMP15 alone has no effects suggest that GDF9:BMP15 heterodimers are involved in the regulation of $\mathrm{AMH}$. Elucidation of $\mathrm{AMH}$ regulation in humans will provide a better understanding of the inter-follicular inhibition of follicle recruitment and will help to more accurately interpret circulating levels of $\mathrm{AMH}$ in clinical applications where it is widely used as a marker of ovarian reserve.

\section{Supplementary data}

This is linked to the online version of the paper at http://dx.doi.org/10.1530/REP-17-0421.

\section{Declaration of interest}

The authors declare no conflict of interest that could beperceived as prejudicing the impartiality of the research reported.

\section{Funding}

This work was supported by the National Institute of Health (grant number R56HD086054 to CS).

\section{References}

Al-Musawi SL, Walton KL, Heath D, Simpson CM \& Harrison CA 2013 Species differences in the expression and activity of bone morphogenetic protein 15. Endocrinology 154 888-899. (doi:10.1210/en.2012-2015)

Andersen CY \& Byskov AG 2006 Estradiol and regulation of anti-Mullerian hormone, inhibin-A, and inhibin-B secretion: analysis of small antral and preovulatory human follicles' fluid. Journal of Clinical Endocrinology and Metabolism 91 4064-4069. (doi:10.1210/jc.2006-1066)

Andersen CY, Schmidt KT, Kristensen SG, Rosendahl M, Byskov AG \& Ernst E 2010 Concentrations of AMH and inhibin-B in relation to follicular diameter in normal human small antral follicles. Human Reproduction 25 1282-1287. (doi:10.1093/humrep/deq019)

Baarends WM, Uilenbroek JT, Kramer P, Hoogerbrugge JW, van Leeuwen EC, Themmen AP \& Grootegoed JA 1995 Anti-Mullerian hormone and anti-Mullerian hormone type II receptor messenger ribonucleic acid expression in rat ovaries during postnatal development, the estrous cycle, and gonadotropin-induced follicle growth. Endocrinology 136 4951-4962. (doi:10.1210/endo.136.11.7588229)

Baumgarten SC, Convissar SM, Fierro MA, Winston NJ, Scoccia B \& Stocco C 2014 IGF1R signaling is necessary for fsh-induced activation of AKT and differentiation of human Cumulus granulosa cells. Journal of Clinical Endocrinology and Metabolism 99 2995-3004. (doi:10.1210/ jc.2014-1139)

Baumgarten SC, Convissar SM, Zamah AM, Fierro MA, Winston NJ, Scoccia B \& Stocco C 2015 FSH regulates IGF-2 expression in human granulosa cells in an AKT-dependent manner. Journal of Clinical Endocrinology and Metabolism 100 E1046-E1055. (doi:10.1210/jc.2015-1504)

Bennett J, Baumgarten SC \& Stocco C 2013 GATA4 and GATA6 silencing in ovarian granulosa cells affects levels of mRNAs involved in steroidogenesis, extracellular structure organization, IGF-I activity, and apoptosis. Endocrinology 154 4845-4858. (doi:10.1210/en.2013-1410)

Blanchard MG \& Josso N 1974 Source of the anti-Mullerian hormone synthesized by the fetal testis: mullerian-inhibiting activity of fetal bovine Sertoli cells in tissue culture. Pediatric Research 8 968-971. (doi:10.1203/00006450-197412000-00011)

Campbell BK, Clinton M \& Webb R 2012 The role of anti-Mullerian hormone (AMH) during follicle development in a monovulatory species (sheep). Endocrinology 153 4533-4543. (doi:10.1210/en.2012-1158)

$\operatorname{deVet}$ A, Laven JS, de Jong FH, Themmen AP \& Fauser BC 2002 Antimullerian hormone serum levels: a putative marker for ovarian aging. Fertility and Sterility 77 357-362. (doi:10.1016/S0015-0282(01)02993-4)

Dewailly D, Andersen CY, Balen A, Broekmans F, Dilaver N, Fanchin R, Griesinger G, Kelsey TW, La Marca A, Lambalk C et al. 2014 The physiology and clinical utility of anti-Mullerian hormone in women. Human Reproduction Update 20 370-385. (doi:10.1093/humupd/ dmt062)

Di Pasquale E, Beck-Peccoz P \& Persani L 2004 Hypergonadotropic ovarian failure associated with an inherited mutation of human bone morphogenetic protein-15 (BMP15) gene. American Journal of Human Genetics 75 106-111. (doi:10.1086/422103)

Di Pasquale E, Rossetti R, Marozzi A, Bodega B, Borgato S, Cavallo L, Einaudi S, Radetti G, Russo G, Sacco M et al. 2006 Identification of new variants of human BMP15 gene in a large cohort of women with premature ovarian failure. Journal of Clinical Endocrinology and Metabolism 91 1976-1979. (doi:10.1210/jc.2005-2650)

Dixit H, Rao LK, Padmalatha VV, Kanakavalli M, Deenadayal M, Gupta N, Chakrabarty B \& Singh L 2006 Missense mutations in the BMP15 gene are associated with ovarian failure. Human Genetics 119 408-415. (doi:10.1007/s00439-006-0150-0)

Dolleman M, Depmann M, Eijkemans MJ, Heimensem J, Broer SL, van der Stroom EM, Laven JS, Van Rooij IA, Scheffer GJ, Peeters PH et al. 2014 Anti-mullerian hormone is a more accurate predictor of individual time to menopause than mother's age at menopause. Human Reproduction 29 584-591. (doi:10.1093/humrep/det446)

Dumesic DA \& Richards JS 2013 Ontogeny of the ovary in polycystic ovary syndrome. Fertility and Sterility 100 23-38. (doi:10.1016/j. fertnstert.2013.02.011)

Dumont A, Robin G, Catteau-Jonard S \& Dewailly D 2015 Role of antimullerian hormone in pathophysiology, diagnosis and treatment of Polycystic Ovary Syndrome: a review. Reproductive Biology and Endocrinology 13 137. (doi:10.1186/s12958-015-0134-9)

Dunlop CE \& Anderson RA 2015 Uses of anti-Mullerian hormone (AMH) measurement before and after cancer treatment in women. Maturitas $\mathbf{8 0}$ 245-250. (doi:10.1016/j.maturitas.2014.12.005)

Durlinger AL, Kramer P, Karels B, de Jong FH, Uilenbroek JT, Grootegoed JA \& Themmen AP 1999 Control of primordial follicle recruitment by anti-Mullerian hormone in the mouse ovary. Endocrinology $\mathbf{1 4 0}$ 5789-5796. (doi:10.1210/endo.140.12.7204)

Durlinger AL, Gruijters MJ, Kramer P, Karels B, Kumar TR, Matzuk MM, Rose UM, de Jong FH, Uilenbroek JT, Grootegoed JA \& Themmen AP 2001 Anti-Mullerian hormone attenuates the effects of FSH on follicle development in the mouse ovary. Endocrinology 142 4891-4899. (doi:10.1210/endo.142.11.8486)

Elvin JA, Yan C, Wang P, Nishimori K \& Matzuk MM 1999 Molecular characterization of the follicle defects in the growth differentiation factor 9-deficient ovary. Molecular Endocrinology 13 1018-1034. (doi:10.1210/mend.13.6.0309)

Galloway SM, McNatty KP, Cambridge LM, Laitinen MP, Juengel JL, Jokiranta TS, McLaren RJ, Luiro K, Dodds KG, Montgomery GW et al. 2000 Mutations in an oocyte-derived growth factor gene (BMP15) cause increased ovulation rate and infertility in a dosage-sensitive manner. Nature Genetics 25 279-283. (doi:10.1038/77033)

Giuili G, Shen WH \& Ingraham HA 1997 The nuclear receptor SF-1 mediates sexually dimorphic expression of Mullerian Inhibiting Substance, in vivo. Development 124 1799-1807.

Gode F, Gulekli B, Dogan E, Korhan P, Dogan S, Bige O, Cimrin D \& Atabey N 2011 Influence of follicular fluid GDF9 and BMP15 on embryo quality. Fertility and Sterility 95 2274-2278. (doi:10.1016/j. fertnstert.2011.03.045)

Grondahl ML, Nielsen ME, Dal Canto MB, Fadini R, Rasmussen IA, Westergaard LG, Kristensen SG \& Yding Andersen C 2011 
Anti-Mullerian hormone remains highly expressed in human cumulus cells during the final stages of folliculogenesis. Reproductive BioMedicine Online 22 389-398. (doi:10.1016/j.rbmo.2010.12.005)

Grynberg M, Pierre A, Rey R, Leclerc A, Arouche N, Hesters L, CatteauJonard S, Frydman R, Picard J-Y, Fanchin R, et al. 2012 Differential regulation of ovarian anti-müllerian hormone $(\mathrm{AMH})$ by estradiol through $\alpha$ - and $\beta$-estrogen receptors. Journal of Clinical Endocrinology and Metabolism 97 E1649-E1657. (doi:10.1210/jc.2011-3133)

Han M, Park SB \& Park BJ 2011 Lower growth factor expression in follicular fluid undergone in-vitro fertilization. Clinical and Experimental Reproductive Medicine 38 210-215. (doi:10.5653/cerm.2011.38.4.210)

Hayashi M, McGee EA, Min G, Klein C, Rose UM, van Duin M \& Hsueh AJ 1999 Recombinant growth differentiation factor-9 (GDF-9) enhances growth and differentiation of cultured early ovarian follicles. Endocrinology 140 1236-1244. (doi:10.1210/endo.140.3.6548)

Ilhan R, Ozkan ZS, Ekinci M, Timurkan H \& İlhan N 2017 What is the impact of serum and follicular fluid BMP-15 and AMH levels in ICSIET cycle outcomes? Histology, Cytology and Embryology $\mathbf{1}$ 1-5. (doi:10.15761/HCE.1000112)

Inman GJ, Nicolas FJ, Callahan JF, Harling JD, Gaster LM, Reith AD, Laping NJ \& Hill CS 2002 SB-431542 is a potent and specific inhibitor of transforming growth factor-beta superfamily type I activin receptor-like kinase (ALK) receptors ALK4, ALK5, and ALK7. Molecular Pharmacology 62 65-74. (doi:10.1124/mol.62.1.65)

Jeppesen JV, Anderson RA, Kelsey TW, Christiansen SL, Kristensen SG, Jayaprakasan K, Raine-Fenning N, Campbell BK \& Yding Andersen C 2013 Which follicles make the most anti-Mullerian hormone in humans? Evidence for an abrupt decline in $\mathrm{AMH}$ production at the time of follicle selection. Molecular Human Reproduction 19 519-527. (doi:10.1093/ molehr/gat024)

Kedem-Dickman A, Maman E, Yung Y, Yerushalmi GM, Hemi R, Hanochi M, Dor J \& Hourvitz A 2012 Anti-Mullerian hormone is highly expressed and secreted from cumulus granulosa cells of stimulated preovulatory immature and atretic oocytes. Reproductive BioMedicine Online $\mathbf{2 4}$ 540-546. (doi:10.1016/j.rbmo.2012.01.023)

Kovanci E, Rohozinski J, Simpson JL, Heard MJ, Bishop CE \& Carson SA 2007 Growth differentiating factor-9 mutations may be associated with premature ovarian failure. Fertility and Sterility 87 143-146. (doi:10.1016/j.fertnstert.2006.05.079)

Lasala C, Carre-Eusebe D, Picard JY \& Rey R 2004 Subcellular and molecular mechanisms regulating anti-Mullerian hormone gene expression in mammalian and nonmammalian species. DNA and Cell Biology 23 572-585. (doi:10.1089/dna.2004.23.572)

Lasala C, Schteingart HF, Arouche N, Bedecarras P, Grinspon RP, Picard JY, Josso N, di Clemente N \& Rey RA 2011 SOX9 and SF1 are involved in cyclic AMP-mediated upregulation of anti-Mullerian gene expression in the testicular prepubertal Sertoli cell line SMAT1. American Journal of Physiology: Endocrinology and Metabolism 301 E539-E547. (doi:10.1152/ajpendo.00187.2011)

Liao WX, Moore RK, Otsuka F \& Shimasaki S 2003 Effect of intracellular interactions on the processing and secretion of bone morphogenetic protein-15 (BMP-15) and growth and differentiation factor-9. Implication of the aberrant ovarian phenotype of BMP-15 mutant sheep. Journal of Biological Chemistry 278 3713-3719. (doi:10.1074/jbc.M210598200)

Lukas-Croisier C, Lasala C, Nicaud J, Bedecarras P, Kumar TR, Dutertre M, Matzuk MM, Picard JY, Josso N \& Rey R 2003 Follicle-stimulating hormone increases testicular Anti-Mullerian hormone $(\mathrm{AMH})$ production through sertoli cell proliferation and a nonclassical cyclic adenosine 5'-monophosphate-mediated activation of the AMH Gene. Molecular Endocrinology 17 550-561. (doi:10.1210/me.2002-0186)

Mazerbourg S, Klein C, Roh J, Kaivo-Oja N, Mottershead DG, Korchynskyi O, Ritvos O \& Hsueh AJ 2004 Growth differentiation factor-9 signaling is mediated by the type I receptor, activin receptorlike kinase 5. Molecular Endocrinology 18 653-665. (doi:10.1210/ me.2003-0393)

McNatty KP, Juengel JL, Reader KL, Lun S, Myllymaa S, Lawrence SB, Western A, Meerasahib MF, Mottershead DG, Groome NP et al. 2005a Bone morphogenetic protein 15 and growth differentiation factor 9 cooperate to regulate granulosa cell function. Reproduction 129 473-480. (doi:10.1530/rep.1.0511)

McNatty KP, Juengel JL, Reader KL, Lun S, Myllymaa S, Lawrence SB, Western A, Meerasahib MF, Mottershead DG, Groome NP et al. 2005b
Bone morphogenetic protein 15 and growth differentiation factor 9 co-operate to regulate granulosa cell function in ruminants. Reproduction 129 481-487. (doi:10.1530/rep.1.00517)

Meduri G, Massin N, Guibourdenche J, Bachelot A, Fiori O, Kuttenn F, Misrahi M \& Touraine $\mathbf{P} 2007$ Serum anti-Mullerian hormone expression in women with premature ovarian failure. Human Reproduction 22 117-123. (doi:10.1093/humrep/del346)

Merhi Z, Buyuk E, Berger DS, Zapantis A, Israel DD, Chua S Jr \& Jindal S 2013 Leptin suppresses anti-Mullerian hormone gene expression through the JAK2/STAT3 pathway in luteinized granulosa cells of women undergoing IVF. Human Reproduction 28 1661-1669. (doi:10.1093/ humrep/det072)

Monestier O, Servin B, Auclair S, Bourquard T, Poupon A, Pascal G \& Fabre S 2014 Evolutionary origin of bone morphogenetic protein 15 and growth and differentiation factor 9 and differential selective pressure between mono- and polyovulating species. Biology of Reproduction 91. (doi:10.1095/biolreprod.114.119735)

Moore RK, Otsuka F \& Shimasaki S 2003 Molecular basis of bone morphogenetic protein-15 signaling in granulosa cells. Journal of Biological Chemistry 278 304-310. (doi:10.1074/jbc.M207362200)

Mottershead DG, Ritter LJ \& Gilchrist RB 2012 Signalling pathways mediating specific synergistic interactions between GDF9 and BMP15. Molecular Human Reproduction 18 121-128. (doi:10.1093/molehr/ gar056)

Mottershead DG, Sugimura S, Al-Musawi SL, Li JJ, Richani D, White MA, Martin GA, Trotta AP, Ritter LJ, Shi J et al. 2015 Cumulin, an oocytesecreted heterodimer of the transforming growth factor-beta family, is a potent activator of granulosa cells and improves oocyte quality. Journal of Biological Chemistry 290 24007-24020. (doi:10.1074/jbc. M115.671487)

Otsuka F, Yao Z, Lee T, Yamamoto S, Erickson GF \& Shimasaki S 2000 Bone morphogenetic protein-15. Identification of target cells and biological functions. Journal of Biological Chemistry 275 39523-39528. (doi:10.1074/jbc.M007428200)

Pankhurst MW 2017 A putative role for anti-Mullerian hormone $(A M H)$ in optimising ovarian reserve expenditure. Journal of Endocrinology 233 R1-R13. (doi:10.1530/JOE-16-0522)

Peng J, Li Q, Wigglesworth K, Rangarajan A, Kattamuri C, Peterson RT, Eppig JJ, Thompson TB \& Matzuk MM 2013 Growth differentiation factor 9: bone morphogenetic protein 15 heterodimers are potent regulators of ovarian functions. PNAS 110 E776-E785. (doi:10.1073/ pnas.1218020110)

Picard JY, Benarous R, Guerrier D, Josso N \& Kahn A 1986 Cloning and expression of cDNA for anti-mullerian hormone. PNAS 83 5464-5468. (doi:10.1073/pnas.83.15.5464)

Pierre A, Estienne A, Racine C, Picard JY, Fanchin R, Lahoz B, Alabart JL, Folch J, Jarrier P, Fabre S et al. 2016 The bone morphogenetic protein 15 up-regulates the anti-Mullerian hormone receptor expression in granulosa cells. Journal of Clinical Endocrinology and Metabolism 101 2602-2611. (doi:10.1210/jc.2015-4066)

Reader KL, Heath DA, Lun S, McIntosh CJ, Western AH, Littlejohn RP, McNatty KP \& Juengel JL 2011 Signalling pathways involved in the cooperative effects of ovine and murine GDF9+BMP15-stimulated thymidine uptake by rat granulosa cells. Reproduction 142 123-131. (doi:10.1530/REP-10-0490)

Salmon NA, Handyside AH \& Joyce IM 2004 Oocyte regulation of antiMullerian hormone expression in granulosa cells during ovarian follicle development in mice. Developmental Biology 266 201-208. (doi:10.1016/j.ydbio.2003.10.009)

Salmon NA, Handyside AH \& Joyce IM 2005 Expression of Sox8, Sf1, Gata4, Wt1, Dax1, and Fog2 in the mouse ovarian follicle: implications for the regulation of Amh expression. Molecular Reproduction and Development 70 271-277. (doi:10.1002/mrd.20208)

Stocco C, Baumgarten SC, Armouti M, Fierro MA, Winston NJ, Scoccia B \& Zamah AM 2017 Genome-wide interactions between FSH and insulin-like growth factors in the regulation of human granulosa cell differentiation. Human Reproduction 32 905-914. (doi:10.1093/ humrep/dex002)

Stove V, Smits K, Naessens E, Plum J \& Verhasselt B 2006 Multiple gene knock-down by a single lentiviral vector expressing an array of short hairpin RNAs. Electronic Journal of Biotechnology 9 572-579. (doi:10.2225/vol9-issue5-fulltext-13) 
Su YQ, Wu X, O'Brien MJ, Pendola FL, Denegre JN, Matzuk MM \& Eppig JJ 2004 Synergistic roles of BMP15 and GDF9 in the development and function of the oocyte-cumulus cell complex in mice: genetic evidence for an oocyte-granulosa cell regulatory loop. Developmental Biology 276 64-73. (doi:10.1016/j.ydbio.2004.08.020)

Sun RZ, Lei L, Cheng L, Jin ZF, Zu SJ, Shan ZY, Wang ZD, Zhang JX \& Liu ZH 2010 Expression of GDF-9, BMP-15 and their receptors in mammalian ovary follicles. Journal of Molecular Histology 41 325-332. (doi:10.1007/s10735-010-9294-2)

Taieb J, Grynberg M, Pierre A, Arouche N, Massart P, Belville C, Hesters L, Frydman R, Catteau-Jonard S, Fanchin R, Picard JY, Josso N, Rey RA \& di Clemente N 2011 FSH and its second messenger CAMP stimulate the transcription of human anti-Mullerian hormone in cultured granulosa cells. Molecular Endocrinology 25 645-655. (doi:10.1210/me.2010-0297)

Teixeira Filho FL, Baracat EC, Lee TH, Suh CS, Matsui M, Chang RJ, Shimasaki S \& Erickson GF 2002 Aberrant expression of growth differentiation factor-9 in oocytes of women with polycystic ovary syndrome. Journal of Clinical Endocrinology and Metabolism 87 1337-1344. (doi:10.1210/jcem.87.3.8316)

Visser JA, Schipper I, Laven JS \& Themmen AP 2012 Anti-Mullerian hormone: an ovarian reserve marker in primary ovarian insufficiency. Nature Reviews Endocrinology 8 331-341.

Weenen C, Laven JS, Von Bergh AR, Cranfield M, Groome NP, Visser JA, Kramer P, Fauser BC \& Themmen AP 2004 Anti-Mullerian hormone expression pattern in the human ovary: potential implications for initial and cyclic follicle recruitment. Molecular Human Reproduction 10 77-83. (doi:10.1093/molehr/gah015)

Yan C, Wang P, DeMayo J, DeMayo FJ, Elvin JA, Carino C, Prasad SV, Skinner SS, Dunbar BS, Dube JL, et al. 2001 Synergistic roles of bone morphogenetic protein 15 and growth differentiation factor 9 in ovarian function. Molecular Endocrinology 15 854-866. (doi:10.1210/ mend.15.6.0662)

Yoshino O, McMahon HE, Sharma S \& Shimasaki S 2006 A unique preovulatory expression pattern plays a key role in the physiological functions of BMP-15 in the mouse. PNAS 103 10678-10683. (doi:10.1073/pnas.0600507103)

Zhang HH, Xu PY, Wu J, Zou WW, Xu XM, Cao XY \& Wei LZ 2014 Dehydroepiandrosterone improves follicular fluid bone morphogenetic protein-15 and accumulated embryo score of infertility patients with diminished ovarian reserve undergoing in vitro fertilization: a randomized controlled trial. Journal of Ovarian Research 7 93. (doi:10.1186/s13048014-0093-3)

Zhao H, Qin Y, Kovanci E, Simpson JL, Chen ZJ \& Rajkovic A 2007 Analyses of GDF9 mutation in 100 Chinese women with premature ovarian failure. Fertility and Sterility 88 1474-1476. (doi:10.1016/j. fertnstert.2007.01.021)

Zhou P, Baumgarten SC, Wu Y, Bennett J, Winston N, Hirshfeld-Cytron J \& Stocco C 2013 IGF-I signaling is essential for FSH stimulation of AKT and steroidogenic genes in granulosa cells. Molecular Endocrinology 27 511-523. (doi:10.1210/me.2012-1307)

Received 11 July 2017

First decision 8 August 2017

Revised manuscript received 15 August 2017

Accepted 5 September 2017 